\title{
Growth and Yield Response of Improved Sweet Potato (Ipomoea batatas (L.) Lam) Varieties to Different Rates of Potassium Fertilizer in Calabar, Nigeria
}

\author{
D. F. Uwah ${ }^{1}$, U. L. Undie ${ }^{2}$, N. M. John ${ }^{1} \&$ G. O. Ukoha ${ }^{1}$ \\ ${ }^{1}$ Departments of Crop/Soil Sciences, University of Calabar, Nigeria \\ ${ }^{2}$ Department of Agronomy, Cross River University of Technology, Obubra Campus, Nigeria \\ Correspondence: D. F. Uwah, Departments of Crop/Soil Sciences, University of Calabar, Calabar, Nigeria. Tel: \\ 234-803-744-4068. E-mail: dfu55@yahoo.ca
}

Received: March 2, 2013 Accepted: May 22, 2013 Online Published: June 15, 2013

doi:10.5539/jas.v5n7p61 URL: http://dx.doi.org/10.5539/jas.v5n7p61

\begin{abstract}
A two-year field study was conducted during the growing seasons of 2007 and 2008 in Calabar, south eastern Nigeria to evaluate the response of two improved sweet potato varieties (TIS 8164 and Ex-Igbariam) to five rates $(0,40,80,120$ and $160 \mathrm{~kg} \mathrm{~K} / \mathrm{ha})$ of potassium fertilizer. Factorial combinations of the treatments were arranged into a randomized complete block design with three replications. Results showed that Ex-Igbariam was more responsive to K application than TIS8164 as indicated by the production of longer vines, higher number of leaves and branches/plant and heavier vine dry weight at all the applied K rates. Averaged across the two years, revealed that Ex-Igbariam out-yielded TIS8164 by 12.5, 12.7 and 13.3\% for number of tubers/plant, weight of tubers/plant and tuber yield/ha, respectively. Application of $\mathrm{K}$ at the highest rate $(160 \mathrm{~kg} / \mathrm{ha})$ significantly $(\mathrm{P}<0.05)$ increased vine length, number of leaves and branches/plant, whereas dry weight of vine, diameter of tubers/plant and weight of tubers/plant were statistically similar at 120 and $160 \mathrm{~kg} \mathrm{~K} / \mathrm{ha}$ rates. Number of tubers/plant and tuber yield/ha peaked at $120 \mathrm{~kg} \mathrm{~K} / \mathrm{ha}$ and $160 \mathrm{~kg} \mathrm{~K} / \mathrm{ha}$, respectively. Aggregate tuber yield/ha obtained at 120 and $160 \mathrm{~kg} \mathrm{~K} / \mathrm{ha}$ rates were more than 7 and 8 times, respectively higher than the control treatments. Potassium fertilizer application at 120 to $160 \mathrm{~kg} / \mathrm{ha}$ appeared appropriate for optimum yield for Ex-Igbariam in the study area and is therefore recommended.
\end{abstract}

Keywords: sweet potato, improved varieties, potassium fertilizer, rates, tuber yield

\section{Introduction}

Sweet potato (Ipomoea batatas (L.) Lam), a member of convolvulaceae family, is a perennial crop usually grown as an annual and a starchy staple food crop in the tropical, sub-tropical and frost-free temperate climatic zones of the world (Onwueme \& Sinha, 1991). It ranks fifth as the most important food crop after rice, wheat, maize and cassava in developing countries (Som, 2007). The crop is known as a highly tolerant tuberous root crop to high temperatures, poor soils, floods and exhibits some resistance to pests and diseases. Sweet potato is usually planted sole or intercropped with other staples such as maize, cassava, yam or okra in West African countries where it is effective in suppressing weed growth in such fields (Eneji et al., 1995).

The potential of sweet potato to guarantee food security is under-estimated as its use is often limited to a substitute food in African countries. Sweet potato is valued for its tubers which are boiled, fried, baked or roasted for humans or boiled and fed to livestock as a source of energy. The tubers can also be processed into flour for bread making, starch for noodles as well as used as raw material for industrial starch and alcohol (Ukom et al., 2009). The flour is utilized also in sweetening local beverages like Kunu-zaki, burukutu, and for fortifying baby foods and foo-foo/pounded yam in Nigeria (Tewe et al., 2003). The leaves are used as vegetables in yam and cocoyam porridge and are rich in proteins, vitamins and various minerals. Sweet potato tubers are rich in vitamins A, B, and $\mathrm{C}$; and minerals such as $\mathrm{K}, \mathrm{Na}, \mathrm{Cl}, \mathrm{P}$ and $\mathrm{Ca}$ (Onwueme \& Sinha, 1991). It can therefore be a high value-added food particularly for children and pregnant women who are more often exposed to vitamin A deficiency in sub-saharan Africa (Degras, 2003).

FAO (2012) reported that 115 countries produced 108,274,685 tonnes of sweet potato in 2010 with China producing the largest, 82,474,410 tonnes, followed by Indonesia, 2,083,623 tonnes. Far behind, but ranked second 
in the world after Asia, is Africa with its contribution of up to $14 \%$ of global production put at $14,441,099$ tonnes in 2010. Nigeria ranks second in Africa after Uganda with the production figure of 2,883,408 tonnes which has shown an increasing trend over the years (FAOSTAT, 2012).

Though sweet potato crop is easy to cultivate, it is faced with some production and economic constraints. Labour costs are high in some localities; yields remain poor on account of low fertility status of the over-cropped soils, while post-harvest losses and low purchase prices have reduced production and deterred investment. Onunka et al. (2012) confirmed that yields of sweet potato is presently restricted by many factors among which are low soil fertility, varietal selection, planting date, weather condition, soil type, weed, insect and disease pressure and crop management practices among others. The crop thrives in marginal soils but improved soil fertility increases its growth and yield performance.

Sweet potato like sugarcane, Irish potato and cassava are crops that have high demands for K because leaves, vines, stems and tubers usually remove substantial quantity of $\mathrm{K}$ from the soil. Potassium appears to be the most important nutrient in the production of sweet potato as its application increases yield by the formation of larger sized tubers. Potassium also affects the number, size, quality and the unit weight of tuberous roots produced, while the minimum levels of $\mathrm{K}$ suggested for healthy growth and yield are twice those recommended for N, although three times as much may be applied and occasionally even more (Degras, 2003). Sweet potato yield is significantly depressed if $\mathrm{K}$ is deficient, but eliminating $\mathrm{P}$ does not seem to affect the yield as the crop is well adapted to low levels of available $\mathrm{P}$ on account of its mycorrhizal association which makes $\mathrm{P}$ available to it. In Japan, it was estimated that a tuberous yield of $13 \mathrm{t} / \mathrm{ha}$, removes about $70 \mathrm{~kg} \mathrm{~N} / \mathrm{ha}, 20 \mathrm{~kg} \mathrm{P} \mathrm{O}_{5} / \mathrm{ha}$ and $110 \mathrm{~kg} \mathrm{~K} 2 \mathrm{O} / \mathrm{ha}$ from the soil depending on the variety, crop duration and agro-climatic region (Degras, 2003). Comparisons of this kind are rare for tropical areas but figures given by IFA (1991) depicted the particular importance of both K especially in the root and $\mathrm{N}$ in the leaves. Common recommendation in most countries is $35-65 \mathrm{~kg} \mathrm{~N}, 50-100 \mathrm{~kg} \mathrm{P}_{2} \mathrm{O}_{5}$ and 80-170 $\mathrm{kg} \mathrm{K} \mathrm{K}_{2} \mathrm{O}$ per hectare (IFA, 1991). In the Hubei province of China, the optimum $\mathrm{K}$ rate varied from 150-300 $\mathrm{kg} \mathrm{K}{ }_{2} \mathrm{O} /$ ha (Jian-wei et al., 2001). Whereas in India, the mean optimum requirement was put at $120 \mathrm{~kg} \mathrm{~K}{ }_{2} \mathrm{O} / \mathrm{ha}$, while the maximum was $160 \mathrm{~kg} \mathrm{~K} \mathrm{~K}_{2} \mathrm{O} /$ ha with a yield response of $6.7 \mathrm{t} / \mathrm{ha}$ (Trehan et al., 2009).

Sweet potato response to applied K is considerably influenced by the variety grown (Trehan, 2007). The varietal response to applied $\mathrm{K}$ is often related to its yield potential and the number of large sized tubers it can produce. Generally, rapid bulking varieties producing large sized tubers respond more to $\mathrm{K}$ than do the varieties with small tubers (Trehan \& Grewal, 1990).

In order to obtain good yield, studies must be conducted on improved varieties of crops which normally do require higher quantities of fertilizers with corresponding higher yield compared to the local varieties. Fertilizer trials on the newly released sweet potato varieties for the south eastern zone of Nigeria by the National Root Crop Research Institute (NRCRI), Umudike, are rare and poorly documented necessitating this field trial. The study was therefore, undertaken to select a suitable sweet potato variety between the two and determine the optimum dose of $\mathrm{K}$ fertilizer for its production in Calabar, south eastern agro-ecology of Nigeria.

\section{Materials and Methods}

Field trial was carried out at the University of Calabar Teaching and Research Farm from March-September in 2007 and 2008 cropping seasons. Calabar is located along the humid coastal region of south eastern Nigeria $\left(4^{\circ} 57^{\prime}\right.$, $8^{\circ} 19^{\prime} ; 37 \mathrm{~m}$ above sea level). This rainfall zone receives 3000 to $3500 \mathrm{~mm}$ rainfall annually which extends from March to November, while the dry season is from December to February. The rainfall pattern is bimodal with long (March-July) and short (September-November) rainy seasons separated by a short dry spell of uncertain length usually in August. The mean annual temperature ranges from $27-35^{\circ} \mathrm{C}$ (Iloeje, 2001). Meteorological data during the two growing seasons are presented in Table 1. The soil is acidic, classified as Ultisol, low in $\mathrm{pH}$, organic matter, and usually deficient in multiple nutrients (Sanchez et al., 1987; Brady \& Weil, 1999).

Two improved varieties of sweet potato (TIS 8164 and Ex-Igbariam), recommended for the rain forest agroecology of Nigeria, obtained from the National Root Crop Research Institute (NRCRI), Umudike, were use in combination with five rates of $\mathrm{K}$ fertilizer $(0,40,80,120$ and $160 \mathrm{~kg} \mathrm{~K} / \mathrm{ha})$, from muriate of potash source $(60 \%$ $\mathrm{K}_{2} \mathrm{O}$ ). Randomized complete block design in a factorial experiment with three replications was used. Soil samples (0-30 cm depths) were collected from the sites prior to fertilizer application and analyzed for physico-chemical properties to determine the baseline fertility status of the trial sites using standard procedures (IITA, 1982). New site was used each year. Relevant results of the physical and chemical analyses of the soils are summarized in Table 2. 
Table 1. Meteorological data at the trial sites during the 2007 and 2008 growing seasons in Calabar, Nigeria

\begin{tabular}{lllllllll}
\hline & \multirow{2}{*}{ Rainfall (mm) } & \multicolumn{3}{c}{ Temperature $\left({ }^{\circ} \mathbf{C}\right)$} & \multicolumn{2}{c}{ Relative humidity (\%) } \\
\cline { 5 - 8 } Month & 2007 & 2008 & 2007 & 2008 & 2007 & 2008 & 2007 & 2008 \\
\hline March & 178.3 & 184.1 & 27.3 & 24.2 & 29.4 & 32.2 & 70 & 82 \\
April & 273.6 & 216.9 & 25.6 & 23.5 & 27.9 & 31.5 & 78 & 86 \\
May & 366.6 & 386.8 & 24.4 & 23.5 & 27.9 & 31.1 & 79 & 88 \\
June & 468.8 & 437.0 & 25.3 & 23.6 & 27.0 & 29.4 & 84 & 89 \\
July & 389.9 & 597.7 & 23.0 & 22.7 & 25.7 & 28.5 & 82 & 91 \\
August & 377.3 & 510.2 & 23.3 & 23.2 & 25.9 & 28.5 & 83 & 90 \\
September & 373.7 & 217.9 & 24.4 & 23.4 & 26.9 & 29.7 & 83 & 88 \\
\hline
\end{tabular}

Source: Department of Geography and Environmental Science, University of Calabar, Nigeria.

Table 2. Physico- chemical properties of top soil $(0-30 \mathrm{~cm}$ depth) of the experimental fields in Calabar, Nigeria

\begin{tabular}{lll}
\hline Composition & 2007 & 2008 \\
\hline Chemical composition $(\mathrm{g} / \mathrm{kg})$ & & 780 \\
Sand & 790 & 60 \\
Silt & 60 & 160 \\
Clay & 150 & Sandy loam \\
Textural class & Sandy loam & \\
\hline Chemical characteristics & & 6.8 \\
$\mathrm{pH}\left(\mathrm{H}_{2} 0\right)(1: 2.5)$ & 6.2 & 5.9 \\
$\mathrm{pH}\left(\mathrm{CaCl}_{2}\right)(1: 2.5)$ & 5.6 & 18.4 \\
Organic Carbon $(\mathrm{g} / \mathrm{kg})$ & 12.5 & 130.0 \\
Available P $(\mathrm{mg} / \mathrm{kg})$ & 93.4 & 1.5 \\
Total N $(\mathrm{g} / \mathrm{kg})$ & 1.4 & \\
\hline Exchangeable bases $(\mathrm{cmol} / \mathrm{kg})$ & & 2.8 \\
Ca & 1.8 & 1.0 \\
$\mathrm{Mg}$ & 0.8 & 0.3 \\
$\mathrm{~K}$ & 0.2 & 0.1 \\
$\mathrm{Na}$ & 0.1 & 0.2 \\
Exchangeable acidity & 0.3 & 6.1 \\
ECEC & 5.0 & 681 \\
Base saturation $(\mathrm{g} / \mathrm{kg})$ & 580 & \\
\hline
\end{tabular}

The sites were slashed and cleared manually without burning, ploughed and harrowed once to a depth of $20 \mathrm{~cm}$ before marking out into three blocks of 10 plots each. Each gross plot size was $4.2 \mathrm{~m} \mathrm{x} 1.8 \mathrm{~m}$ and the net plot size from which growth and yield attributes were estimated was $1.8 \mathrm{~m}$ x $1.2 \mathrm{~m}$. Plots were separated by a path of $1 \mathrm{~m}$, while blocks were separated by a path of $1.5 \mathrm{~m}$. Planting was done on flat beds (dimensions $4.2 \mathrm{~m}$ long, $1.8 \mathrm{~m}$ wide and $25 \mathrm{~cm}$ high) on 9th March in both years. Vine cuttings of $25-30 \mathrm{~cm}$ in length with 5-6 nodes from the terminal shoots with the lower leaves removed, were inserted to half their length slanting at an angle of $45^{\circ}$. The cuttings were spaced $60 \mathrm{~cm} \times 30 \mathrm{~cm}$, one per stand to give 42 plants per plot and 55,555 plants per hectare. Nitrogen (Urea $46 \% \mathrm{~N}$ ) and phosphorus (single super phosphate $18 \% \mathrm{P}_{2} \mathrm{O}_{5}$ ) at the rates of $60 \mathrm{~kg} \mathrm{~N} / \mathrm{ha}$ and $50 \mathrm{~kg} \mathrm{P}_{2} \mathrm{O}_{5} / \mathrm{ha}$ respectively, were applied in a single dose with half the $\mathrm{K}$ dose, two weeks after sowing (WAS) via side banding, 
$10 \mathrm{~cm}$ away from the cuttings. The crops were side-dressed with the second half of K $6 \mathrm{WAS}, 15 \mathrm{~cm}$ away from the cuttings. Manual weeding was done thrice at 2, 6 and 10 WAS using hoe at the early growth stage and hand pulling at later crop growth stage. Earthing up was also carry out at the same time as weeding operation. Harvesting was done in September of each year, 6 months after sowing by carefully digging out the tubers with native hoe and sharpened sticks.

From the 12 plants in the net plot areas, the following growth and yield attributes were determined: length of vine, number of leaves/plant, number of branches/plant, dry weight of vine, number of tubers/plant, weight of tubers/plant, diameter of tubers/plant, length of tubers/plant and fresh tubers yield. Data generated were subjected to analysis of variance using Genstat Release 7.22De Statistical Software (Lawes Agricultural Trust, 2008) and treatment effects were tested for significance at 5\% level of probability.

\section{Results}

Table 1 shows the meteorological data during the two growing seasons. The total amount of fainfall during the 2 nd season cropping $(2550.6 \mathrm{~mm})$ exceeded that of the $1^{\text {st }}$ season cropping $(24282 \mathrm{~mm})$ by $5.0 \%$, while the average monthly temperatures were almost the same for the two seasons $26.0^{\circ} \mathrm{C}$ and $26.8^{\circ} \mathrm{C}$ for the $1^{\text {st }}$ and $2^{\text {nd }}$ cropping seasons respectively. Table 2 presents the soil analysis data of the experimental sites in 2007 and 2008 growing seasons. The sandy loam soils were low in organic carbon, total $\mathrm{N}$, exchangeable $\mathrm{K}$ especially in 2007 ; adequate in available $P$ and slightly acidic in reaction.

\subsection{Effect of Variety}

The growth, yield and yield contributing characters of the two sweet potato varieties are presented in Table 3-5. The results revealed that all the above-mentioned characters varied significantly $(\mathrm{P}<0.05)$ due to varietal differences with Ex-Igbariam variety having advantage over TIS8164 variety in the two years of trial. Longer vine, higher number of leaves and branches/plant (Tables 3 ) and heavier dry weight of vine (Table 4) were exhibited by Ex-Igbariam over TIS8164 variety. Ex-Igbariam produced dry weight of vine that was 8.8 and $11.2 \%$ heavier than that of TIS 8164 in 2007 and 2008, respectively (Table 4). The number of tubers/plant produced by Ex-Igbariam was 9.5 and 15.4\% higher than that of TIS 8164 in 2007 and 2008, respectively. Similarly, the weight of tubers/plant were 13.2 and $12.2 \%$ heavier, while tuber yield/ha were 14.4 and $12.3 \%$ higher than those obtained from TIS 8164 in 2007 and 2008, respectively (Table 5).

Table 3. Vine length, number of leaves/plant and number of branches/plant at 11 weeks after sowing as influenced by $\mathrm{K}$ fertilizer and sweet potato variety in 2007 and 2008 in Calabar, Nigeria

\begin{tabular}{|c|c|c|c|c|c|c|c|c|c|}
\hline \multirow[b]{2}{*}{ Treatment } & \multicolumn{3}{|c|}{ Variety } & \multicolumn{3}{|l|}{ Variety } & \multicolumn{3}{|c|}{ Variety } \\
\hline & $\begin{array}{l}\text { TIS } \\
8164\end{array}$ & Ex-Igba & Mean & $\begin{array}{l}\text { TIS } \\
8164\end{array}$ & Ex-Igba & Mean & $\begin{array}{l}\text { TIS } \\
8164\end{array}$ & Ex-Igba & Mean \\
\hline $\begin{array}{l}\text { Potassium } \\
(\mathrm{kg} / \mathrm{ha})\end{array}$ & \multicolumn{3}{|c|}{$\begin{array}{l}\text { Length of vine }(\mathrm{cm}) \\
(2007)\end{array}$} & \multicolumn{3}{|c|}{$\begin{array}{l}\text { Number of leaves/plant } \\
(2007)\end{array}$} & \multicolumn{3}{|c|}{$\begin{array}{l}\text { Number of branches/plant } \\
\text { (2007) }\end{array}$} \\
\hline 0 & 136.0 & 145.2 & 140.6 & 170.0 & 178.3 & 174.2 & 9.6 & 11.3 & 10.4 \\
\hline 40 & 157.2 & 160.9 & 159.1 & 180.1 & 187.6 & 183.9 & 11.8 & 13.8 & 12.8 \\
\hline 80 & 160.0 & 168.5 & 164.2 & 188.7 & 199.2 & 193.9 & 12.4 & 14.6 & 13.5 \\
\hline 120 & 162.7 & 171.6 & 167.1 & 197.4 & 205.5 & 201.5 & 13.6 & 15.7 & 14.7 \\
\hline 160 & 174.5 & 180.9 & 177.7 & 202.3 & 211.9 & 207.1 & 14.7 & 16.3 & 15.5 \\
\hline Mean & 158.1 & 165.4 & & 187.7 & 196.5 & & 12.4 & 14.3 & \\
\hline $\mathrm{K}(\mathrm{kg} / \mathrm{ha})$ & (2008) & & & (2008) & & & (2008) & & \\
\hline 0 & 133.2 & 142.7 & 138.0 & 165.8 & 180.5 & 173.2 & 10.4 & 11.5 & 11.0 \\
\hline 40 & 152.8 & 151.2 & 152.0 & 182.4 & 196.5 & 189.5 & 12.3 & 14.4 & 13.4 \\
\hline 80 & 159.7 & 168.9 & 164.3 & 190.2 & 204.2 & 197.2 & 13.4 & 15.4 & 14.4 \\
\hline 120 & 163.5 & 177.0 & 170.2 & 201.7 & 209.5 & 205.6 & 14.2 & 16.5 & 15.4 \\
\hline 160 & 175.1 & 203.7 & 189.4 & 207.5 & 215.4 & 211.5 & 15.5 & 17.1 & 16.3 \\
\hline Mean & 156.9 & 168.7 & & 189.5 & 201.2 & & 13.2 & 15.0 & \\
\hline
\end{tabular}

LSD (0.05) between treatment means.

NS $=$ Not significant. 


\begin{tabular}{lccc}
\hline & Length of vine $(\mathrm{cm})$ & Number of leaves/plant & Number of branches/plant \\
\hline \multirow{2}{*}{ Potassium fertilizer (K) } & 2007 & 2007 & 2007 \\
Variety (V) & 5.16 & 3.52 & 0.91 \\
K x V & 3.27 & 2.23 & 0.57 \\
& NS & NS & NS \\
Potassium fertilizer (K) & 2008 & 2008 & 2008 \\
Variety (V) & 13.93 & 3.97 & 0.76 \\
K x V & 8.81 & 2.51 & 0.48 \\
\hline
\end{tabular}

Table 4. Dry weight of vine $(\mathrm{g})$ at 11 weeks after sowing, length of tubers/plant $(\mathrm{cm})$ and diameter of tubers/plant $(\mathrm{cm})$ as influenced by K fertilizer and sweet potato variety in 2007 and 2008 in Calabar, Nigeria

\begin{tabular}{|c|c|c|c|c|c|c|c|c|c|}
\hline \multirow[b]{2}{*}{ Treatment } & \multicolumn{3}{|c|}{ Variety } & \multicolumn{3}{|c|}{ Variety } & \multicolumn{3}{|c|}{ Variety } \\
\hline & $\begin{array}{l}\text { TIS } \\
8164\end{array}$ & Ex-Igba & Mean & $\begin{array}{l}\text { TIS } \\
8164\end{array}$ & Ex-Igba & Mean & $\begin{array}{l}\text { TIS } \\
8164\end{array}$ & Ex-Igba & Mean \\
\hline $\begin{array}{l}\text { Potassium } \\
(\mathrm{kg} / \mathrm{ha})\end{array}$ & \multicolumn{3}{|c|}{$\begin{array}{l}\text { Dry weight of vine } \\
\text { (2007) }\end{array}$} & \multicolumn{3}{|c|}{$\begin{array}{l}\text { Length tubers/plant } \\
\text { (2007) }\end{array}$} & \multicolumn{3}{|c|}{$\begin{array}{l}\text { Diameter of tubers/plant } \\
\text { (2007) }\end{array}$} \\
\hline 0 & 13.6 & 14.8 & 14.2 & 10.9 & 11.3 & 11.1 & 5.3 & 6.1 & 5.7 \\
\hline 40 & 15.3 & 16.7 & 16.0 & 13.4 & 14.7 & 14.1 & 6.3 & 8.4 & 7.4 \\
\hline 80 & 16.1 & 17.9 & 17.0 & 15.3 & 16.5 & 15.9 & 8.3 & 9.0 & 8.6 \\
\hline 120 & 17.2 & 18.7 & 18.0 & 16.5 & 17.4 & 17.0 & 10.3 & 11.6 & 11.0 \\
\hline 160 & 17.6 & 19.1 & 18.4 & 15.7 & 16.5 & 16.1 & 10.5 & 12.3 & 11.4 \\
\hline Mean & 16.0 & 17.4 & & 14.4 & 15.3 & & 8.1 & 9.5 & \\
\hline $\mathrm{K}(\mathrm{kg} / \mathrm{ha})$ & (2008) & & & $(2008)$ & & & (2008) & & \\
\hline 0 & 13.6 & 15.0 & 14.3 & 10.8 & 11.1 & 10.9 & 5.3 & 6.5 & 5.9 \\
\hline 40 & 15.7 & 17.7 & 16.7 & 13.8 & 14.7 & 14.2 & 7.6 & 9.5 & 8.6 \\
\hline 80 & 17.5 & 19.5 & 18.5 & 15.2 & 17.6 & 16.4 & 9.9 & 11.2 & 10.5 \\
\hline 120 & 19.1 & 21.4 & 20.0 & 18.5 & 19.5 & 19.0 & 12.9 & 14.1 & 13.5 \\
\hline 160 & 19.3 & 20.8 & 20.2 & 16.6 & 18.5 & 17.6 & 12.6 & 14.1 & 13.4 \\
\hline Mean & 17.0 & 18.9 & & 15.0 & 16.3 & & 9.7 & 10.1 & \\
\hline
\end{tabular}

LSD (0.05) between treatment means.

NS = Not significant.

\begin{tabular}{lccc}
\hline & Dry weight of vine $(\mathrm{g})$ & Length of tubers/plant $(\mathrm{cm})$ & Diameter of tubers/plant(cm) \\
\hline \multirow{2}{*}{ Potassium fertilizer (K) } & 2007 & 2007 & 2007 \\
Variety (V) & 1.45 & 1.36 & 1.94 \\
K x V & 0.91 & 0.86 & 1.23 \\
& $\mathrm{NS}$ & $\mathrm{NS}$ & $\mathrm{NS}$ \\
& & & \\
Potassium fertilizer (K) & 2008 & 2008 & 2008 \\
Variety (V) & 1.38 & 1.78 & 1.71 \\
K x V & 0.87 & 1.13 & 1.08 \\
\hline
\end{tabular}


Table 5. Number of tubers/plant, weight of tubers/plant $(\mathrm{kg})$ and tuber yield $(\mathrm{t} / \mathrm{ha})$ as influenced by $\mathrm{K}$ fertilizer and sweet potato variety in 2007 and 2008 in Calabar, Nigeria

\begin{tabular}{|c|c|c|c|c|c|c|c|c|c|}
\hline \multirow[b]{2}{*}{ Treatment } & \multicolumn{3}{|c|}{ Variety } & \multicolumn{3}{|c|}{ Variety } & \multicolumn{3}{|c|}{ Variety } \\
\hline & $\begin{array}{l}\text { TIS } \\
8164\end{array}$ & Ex-Igba & Mean & $\begin{array}{l}\text { TIS } \\
8164\end{array}$ & Ex-Igba & Mean & $\begin{array}{l}\text { TIS } \\
8164\end{array}$ & Ex-Igba & Mean \\
\hline $\begin{array}{l}\text { Potassium } \\
\text { (kg/ha) }\end{array}$ & \multicolumn{3}{|c|}{$\begin{array}{l}\text { Number of tubers/plant } \\
(2007)\end{array}$} & \multicolumn{3}{|c|}{$\begin{array}{l}\text { Weight of tubers/plant }(\mathrm{kg}) \\
(2007)\end{array}$} & \multicolumn{3}{|c|}{$\begin{array}{l}\text { Tuber yield (t/ha) } \\
(2007)\end{array}$} \\
\hline 0 & 4.2 & 4.7 & 4.5 & 0.07 & 0.08 & 0.08 & 4.1 & 4.4 & 4.3 \\
\hline 40 & 5.7 & 6.5 & 6.1 & 0.15 & 0.23 & 0.19 & 8.1 & 12.8 & 10.5 \\
\hline 80 & 7.7 & 8.2 & 7.9 & 0.42 & 0.49 & 0.46 & 23.5 & 27.2 & 25.4 \\
\hline 120 & 7.9 & 8.4 & 8.2 & 0.57 & 0.63 & 0.60 & 30.6 & 35.0 & 32.8 \\
\hline 160 & 5.9 & 6.9 & 6.4 & 0.68 & 0.72 & 0.70 & 37.6 & 39.8 & 38.7 \\
\hline Mean & 6.3 & 6.9 & & 0.38 & 0.43 & & 20.8 & 23.8 & \\
\hline $\mathrm{K}(\mathrm{kg} / \mathrm{ha})$ & (2008) & & & (2008) & & & (2008 & & \\
\hline 0 & 4.0 & 5.3 & 4.7 & 0.08 & 0.09 & 0.08 & 4.3 & 4.8 & 4.6 \\
\hline 40 & 5.9 & 7.0 & 6.5 & 0.18 & 0.24 & 0.21 & 9.8 & 13.5 & 11.7 \\
\hline 80 & 8.1 & 8.7 & 8.4 & 0.45 & 0.53 & 0.49 & 25.2 & 29.6 & 27.4 \\
\hline 120 & 8.1 & 9.0 & 8.6 & 0.62 & 0.70 & 0.66 & 34.6 & 38.9 & 36.8 \\
\hline 160 & 6.5 & 7.5 & 7.0 & 0.71 & 0.73 & 0.72 & 39.6 & 40.7 & 40.2 \\
\hline Mean & 6.5 & 7.5 & & 0.41 & 0.46 & & 22.7 & 25.5 & \\
\hline
\end{tabular}

LSD (0.05) between treatment means.

NS $=$ Not significant.

\begin{tabular}{lccc}
\hline & Number of tubers/plant & Weight of tubers/plant (kg) & Tuber yield (t/ha) \\
\hline \multirow{2}{*}{ Potassium fertilizer (K) } & 2007 & 2007 & 2007 \\
Variety (V) & 0.61 & 0.06 & 3.43 \\
K x V & 0.38 & 0.04 & 2.17 \\
& $\mathrm{NS}$ & $\mathrm{NS}$ & $\mathrm{NS}$ \\
& & & \\
Potassium fertilizer (K) & 2008 & 2008 & 2008 \\
Variety (V) & 0.79 & 0.07 & 3.89 \\
K x V & 0.50 & 0.04 & 2.46 \\
\hline
\end{tabular}

\subsection{Effect of Potassium Fertilizer}

Vine length, number of leaves and branches/plant obtained at the $160 \mathrm{~kg} \mathrm{~K} /$ ha rate were statistically higher than those at the other rates in both years of trial except in 2007 where the number of branches/plant obtained at 120 and $160 \mathrm{~kg} \mathrm{~K} /$ ha rates were statistically similar (Table 3). In 2007, the dry weight of vine produced at 80,120 and 160 $\mathrm{kg} \mathrm{K} / \mathrm{ha}$ rates were statistically similar but heavier than that of the other rates, whereas, in 2008, the $120 \mathrm{and} 160 \mathrm{~kg}$ $\mathrm{K} / \mathrm{ha}$ rates produced dry weight of vine that were statistically at par but heavier than those at the other $\mathrm{K}$ rates. In 2007 , increasing the $\mathrm{K}$ rates from 120 to $160 \mathrm{~kg} \mathrm{~K} / \mathrm{ha}$, only produced a $2.2 \%$ increase in vine dry weight while in 2008 a marginal increase of $1.0 \%$ was recorded (Table 4). Averaged across the two years indicated that, increases in $\mathrm{K}$ rates to 120 and $160 \mathrm{~kg} / \mathrm{ha}$, increased the vine dry weight by 33.3 and $35.4 \%$ respectively, over the control.

In both years, length of tubers peaked at $120 \mathrm{~kg} \mathrm{~K} / \mathrm{ha}$ even though this was statistically similar to what were obtained at 80 and $160 \mathrm{~kg} \mathrm{~K} / \mathrm{ha}$ rates in 2007 and $160 \mathrm{~kg} \mathrm{~K} / \mathrm{ha}$ in 2008. Similar trend was observed with tuber 
diameter in which the 120 and $160 \mathrm{~kg} \mathrm{~K} /$ ha rates produced statistically similar tuber diameter which were higher than those at other rates (Table 4). Each incremental rate of $\mathrm{K}$ significantly increased the number of tubers/plant only up to the $120 \mathrm{~kg} / \mathrm{ha}$ rate in both years. Averaged over the two years, increases in K rates from 0 to $40 \mathrm{~kg} / \mathrm{ha}$, increased the number of tubers by $37 \%$; a further increase to $80 \mathrm{~kg} / \mathrm{ha}$, resulted in $77.2 \%$ increase in the number of tubers, while a further increase to $120 \mathrm{~kg} / \mathrm{ha}$, further increased the number of tubers by 82.6 percent. A further increase to $160 \mathrm{~kg} / \mathrm{ha}$, however, resulted in a $25.4 \%$ reduction in the number of tubers below the $120 \mathrm{~kg} / \mathrm{ha}$ rate (Table 5).

In 2007 , the $160 \mathrm{~kg} \mathrm{~K} /$ ha rate maximized the weight of tubers/plant, while in 2008 , the values for weight of tubers/plant obtained at 120 and $160 \mathrm{~kg} \mathrm{~K} /$ ha rates were statistically similar but superior to the other rates. Tuber yield/ha increased consistently with increasing rates of $\mathrm{K}$ from 0 to $160 \mathrm{~kg} / \mathrm{ha}$ rates in the two years of trial. The difference in yield increase between 120 and $160 \mathrm{~kg} / \mathrm{ha}$ rates was however, not significant in 2008. The application of 40, 80, 120 and $160 \mathrm{~kg} \mathrm{~K} / \mathrm{ha}$, gave an aggregate tuber yield of 149.4, 493.3, 682.0 and $786.5 \%$ respectively, over zero application. In addition to yield increases, plant receiving $120-160 \mathrm{~kg}$ $\mathrm{K} / \mathrm{ha}$ appeared to produce very lustrous tubers, the lustrous appearance of the tuber being higher at the highest rate of $\mathrm{K}$. The $\mathrm{K} \times \mathrm{V}$ interaction was not significant for any of the attributes measured.

\section{Discussion}

Ex-Igbariam variety was more responsive to K application than TIS8164 based on the assessed growth and yield attributes. The more K efficient Ex-Igbariam produced an aggregate tuber yield of $24.7 \mathrm{t} / \mathrm{ha}$, whereas TIS8164 tuber yield was $21.8 \mathrm{t} / \mathrm{ha}-13.3 \%$ lower than that of the former. This agrees with the findings of Sharma and Trehan (2005) and Trehan (2007) which indicated that potato response to applied K is considerably influenced by the variety grown, soil types and agro-climatic zones; and is often related to its yield potential and the number of large sized tubers it can produce as K application is known to increase the tuber size (Trehan \& Grewal, 1990).

The longer vines, higher number of leaves and branches, heavier dry weight of vines and other superior yield attributes exhibited by Ex-Igbariam over TIS8164 variety may be due to genetic factors, but are equally highly influenced by the environmental factors (Vanaja \& Babu, 2006; Yadeta et al., 2011; Narasimhulu et al., 2012 ). Villagarcia (1996) found that the response of sweet potato to $\mathrm{N}$ fertilizer application depended highly on genotypic and environmental variations. The better performance of Ex-Igbariam over TIS8164 in tuber yield could also be attributed to longer vines and higher number of leaves. This conforms with the findings of Brady and Weil (1999) that crop yield is dependent on the amount of foliage present on the plant.

Generally, the application of $\mathrm{K}$ fertilizer at higher rates (120-160 kg/ha), significantly increased vine length, number of leaves and branches/plant and dry weight of vine in the two years of trial. Njoku et al. (2001) had earlier reported that $\mathrm{N}$ and $\mathrm{K}$ were critical to sweet potato production, while Trehan et al. (2009) observed that $\mathrm{K}$ increased vine length, crop vigour, leaf expansion particularly at early stages of growth and extended leaf area duration. This positive response of growth characters to the applied $\mathrm{K}$ is attributable to its role in cell multiplication and photosynthesis in conjunction with $\mathrm{N}$, which gave rise to increase in length of vine, number of leaves and branches and consequent heavier dry weights of vine.

Potassium application increased the size but not the total number of tubers at rates higher than $120 \mathrm{~kg} / \mathrm{ha}$. Across the years, the $120 \mathrm{~kg} /$ ha rate produced more than one and a half times the total number of tubers obtained from the control plots (Table 5). This agrees with the findings of Njoku et al. (2001) and Trehan et al. (2009). Tuber yield increased with added $\mathrm{K}$ up to the highest rate $(160 \mathrm{~kg} / \mathrm{ha})$, suggesting that the $\mathrm{K}$ application increased yield through the formation of large sized tubers. Tuber weight, starch content and lustrous appearance of the surface of the tubers (indicators of quality) have been shown to increase with $\mathrm{K}$ rate up to a maximum of $225 \mathrm{~kg} \mathrm{~K} 2 \mathrm{O} / \mathrm{ha}$, with the application of $150 \mathrm{~kg} \mathrm{~K}_{2} \mathrm{O} /$ ha producing the optimum values for these quality indicators (Jian-wei et al., 2001).

The positive response shown by yield characters to $\mathrm{K}$ could be directly linked to the well-developed photosynthetic surfaces (vine length, number of leaves and branches) and increased physiological activities leading to more assimilates being produced and subsequently translocated and utilized in rapid tuber development and production. Potassium is known to activate a number of enzymes involved in photosynthesis, carbohydrate and protein metabolism and assists in the translocation of carbohydrates from leaves to tubers and tuberous roots of crops where carbohydrates are the main storage material (Mengel \& Kirkby, 2001; Trehan et al., 2009). Hence, the positive response of tuber yield and yield components to increased rate of $\mathrm{K}$ could be attributed to high starch synthesis and translocation activities stimulated by $\mathrm{K}$ application. Optimum tuber yield of sweet potato has been obtained by applying 150-300 $\mathrm{kg} \mathrm{K}_{2} \mathrm{O} / \mathrm{ha}$ (Jian-wei et al., 2001), Trehan et al. (2009) also obtained optimum tuber yield with $120 \mathrm{~kg} \mathrm{~K}_{2} \mathrm{O} / \mathrm{ha}$, while the maximum yield was at $160 \mathrm{~kg} \mathrm{~K}_{2} \mathrm{O} / \mathrm{ha}$. Our results conform with the reports by IFA (1991), Njoku et al. (2001) and Degras (2003) that the application of 80-170 $\mathrm{kg} \mathrm{K}_{2} \mathrm{O} / \mathrm{ha}$ may be adequate 
for continuous sweet potato tuber production provided this is adequately balanced with the needed $\mathrm{N}$ and $\mathrm{P}$ fertilizer requirements..

\section{Conclusion}

This study has demonstrated that sweet potato responded to $\mathrm{K}$ application up to the $160 \mathrm{~kg} / \mathrm{ha}$ rate based on improved growth, tuber yield and tuber appearance. The two varieties responded differently in relation to $\mathrm{K}$ requirement with Ex-Igbariam being more responsive than TIS8164. The application of K at $120-160 \mathrm{~kg} / \mathrm{ha}$ appeared appropriate for optimum yield in our study area. Production of sweet potato on these soils would therefore require $\mathrm{K}$ in the fertilizer regime unless the pre-planting soil test result is shown to be adequate in potassium.

\section{References}

Brady, N. C., \& Weil, R. R. (1999). The Nature and Properties of Soils (12th ed). Prentice-Hall Inc. New Jersey, USA.

Degras, L. (2003). Sweet potato. The Tropical Agriculturalist. Malaysia: Macmillan Publishers Ltd.

Eneji, A. E., Agboola, A. A., \& Isola, O. (1995). The weed suppressive ability of sweet potato in a cassava + maize + sweet potato intercrop. Nigerian Journal of Weed Science, 8, 13-18.

FAOSTAT, Février. (2012). Statistical Database (online) Accessed January 28, 2013, from www.unctad.info/en/infocomm/aacp-products

IFA (International Fertilizer Industry Association). (1992). World fertilizer Use Manual. Publication of International Fertilizer Industry Association (pp. 138-142).

IITA (International Institute of Tropical Agriculture). (1982). Selected methods of soil and plant analysis. International Institute of Tropical Agriculture Manual Series No. 7 Ibadan. Nigeria.

Iloeje, N. P. (2001). A new geography of Nigeria. (New revised ed.) Longman Nigeria Plc.

Jian-wei, L. Fang, C., You-sheng, X., Yun-fan, W., \& Dong-bi, L. (2001). Sweet potato response to potassium. Better Crops International, 15(1), 10-12.

Lawes Agricultural Trust. (2008). GENSTAT Release 7.22 De Reference Manuel. VSN International, Hemel Hempstead, Hertfordshire, UK.

Narasimhulu, R., Kenchanagourdar, P. V., \& Gowda, M. V. C. (2012). Study of genetic variability and correlations in selected groundnut genotypes. International Applied Biology \& Pharmaceutical Technology, $3(1), 355-358$.

Njoku, J. C., Okpara, D. A., \& Asiegbu, J. E. (2001). Growth and yield response of sweet potato to inorganic nitrogen and potassium in a tropical Ultisol. Nigerian Agricultual Journal, 32, 30-41.

Onunka, N. A., Chukwu, L. I., Mbanasor, E. O., \& Ebeniro, C. N. (2012). Effect of organic and inorganic manures and time of application on soil properties and yield of sweet potato in a tropical ultisol. Journal of Agriculture \& Social Reseach, 12(1), 182-193.

Onwueme, I. C., \& Sinha, T. O. (1991). Field crop production in Tropical Africa, principles and practice (pp. 267-275). CTA (Technical Centre for Agriculture and Rural Cooperation) Ede, The Netherlands.

Sanchez, P. A., Stoner, E. R., \& Pushparajah, E. D. (1987). Management of acid tropical soils for sustainable agriculture. Proceeding of IBSRAM Inaugural Workshop, Bangkok, Thailand.

Sharam, R. C., \& Trehan, S. P. (2005). Differences in phosphorus use efficiency in potato genotypes. Advanced in Horticultural Sciences, 19(1), 13-20.

Som, D. (2007) Handbook of horticulture (pp. 512-416). New Delhi: India Council of Agricultural Research.

Tewe, O. O., Abu, O. A., Ojeniyi, E. F., \& Nwokocha, N. H. (2003). In M. O. Akoroda, \& J. M. Ngere (Eds.), Proceedings of the Triennial Symposium of the International Society for Tropical Root Crops (pp. 65-74). African Branch (ISTRC - AB).

Trehan, S. P. (2007). Efficiency of potassium utilization from soil as influenced by different potato cultivars in the absence and presence of green manure (Sesbania aculeate). Advanced in Horticultural Sciences, 21(3), 156-164. 
Trehan, S. P., \& Grewal, J. S. (1990). Effect of time and level of potassium application on tuber yield and potassium composition of plant tissue and tubers of two cultivars. In Potato production, marketing, storage and processing. Indian Agriccultual Reseach Institute. (IARI). New Delhi.

Trehan, S. P., Pandey, S. K., \& Bansal, S. K. (2009). Potassium nutrition of potato crops - The Indian Scenario (pp. 2-9). e-ife No. 19.

Ukom, A. N., Ojimelukwe, P. C., \& Okpara, D. A. (2009). Nutrient composition of selected sweet potato [Ipomoea batatas (L.) Lam] varieties as influenced by different levels of nitrogen fertilizer application. Pakistan Journal of Nutrition, 8(11), 1791-1795. http://dx.doi.org/10.3923/pjn.2009.1791.1795

Vanaja, T., \& Babu, L. C. (2006). Variability in grain quality attributes of high yielding rice varieties (Oryza sativa L.) of diverse orgin. Journal of Tropical Agriculture, 44(1-2), 61-63.

Villagarcia, O. M. R. (1996). Analysis of sweet potato growth under different rates of nitrogen fertilizer. $\mathrm{Ph} . \mathrm{D}$ Thesis. North Carolina State University, NC. USA.

Yadeta, B., Belew, D., Gebreselassie, W., \& Marame, F. (2011). Variability, heritability and genetic advance in hot pepper (Capsicum annuum L.) genotypes in West Shoa, Ethiopia. American - Eurasian Journal of Agriculture and Environmental Science, 10(4), 587-592.

\section{Copyrights}

Copyright for this article is retained by the author(s), with first publication rights granted to the journal.

This is an open-access article distributed under the terms and conditions of the Creative Commons Attribution license (http://creativecommons.org/licenses/by/3.0/). 